\title{
MISSILE WOUNDS SINCE THE SECOND WORLD WAR*
}

\author{
Brigadier J. M. MATHESON, O.B.E., M.D., M.R.C.P., F.R.C.S., late R.A.M.C.** \\ Consulting Surgeon to the British Army of the Rhine
}

MAY I express my deep appreciation and that of my colleagues in the Royal Army Medical Corps for the honour the Committee of Management has done to us in inviting me to give this address on the 25th anniversary of the loss of Alex Simpson-Smith (Fig. 1), talented surgeon, war-time Lieutenant-Colonel, Royal Army Medical Corps and wartime colleague. His loss was part of the heavy price our country paid to buy the peace it has since worked so hard to maintain in this troubled world.

In the spring of 1941, the Cyrenaican port of Tobruk had been beleaguered by enemy forces but a determined thrust by our desert force, the 8th Army, lifted the siege in December, 1941 and threw Rommel's Army some 300 miles westwards to Aghelia. This enabled the stouthearted but weary staff of the 62nd General Hospital in Tobruk to be relieved in January, 1942 by men fresh from our base in Egypt. Simpson-Smith relieved Lieutenant-Colonel (later Sir) Ralph Marnham who had done magnificent work as Officer in Charge of the Surgical Division.

I was Assistant Director of Medical Services of the Tobruk Base Area and when I met Simpson-Smith for the first time after his arrival I was impressed by his eagerness and excitement at having the opportunity of working in the forward area. At the time of his arrival casualties were streaming into the hospital which was acting as a Casualty Clearing Station, for Rommel had counter-attacked and pushed our forces back to within an uncomfortably short distance of Tobruk. Alex Simpson-Smith threw himself with enthusiasm into the task facing him and quickly established himself as an inspiring, dynamic and hard working leader of a fine team of medical officers.

The conditions under which he worked were far from sophisticated. The hospital, housed in bomb-scarred Italian barracks within a stone's throw of the port, was unattractive and bustling with activity. Surgery continued despite rationing of brackish water supplies and of food, the blackout and dust storms. Recurrent attacks by Stuka divebombers on the port were an unnerving distraction and often interfered with the movement and evacuation of patients by hospital ship.

During February the front stabilised and with easing of the pressure I was able to see more of Simpson-Smith and his staff who remained very busy but undaunted. By May it was obvious the Germans were going to make a determined effort to push forward and when the thrust came it threw our forces back into Egypt. Tobruk fell in June, 1942 after fierce fighting and its garrison was captured. After he had patched up all the wounded the grim prospect of captivity was too much for Simpson-Smith and in keeping with his determined and adventurous spirit he made a bold escape by ambulance car in the early days of July. How far he got is not known, but he was not seen again.

He was 42 years old. Undaunted by adversity, the pattern of his life and work were in the highest traditions of our profession and our Corps.

In those few months in Tobruk Simpson-Smith acquired first hand experience of missile wounds and burns. Liberal blood supplies for transfusion were not to appear

\footnotetext{
* The Twentieth Alex Simpson-Smith Memorial Lecture at the West London Hospital on 6th July, 1967.
} ** Now Consulting Surgeon, Far East Land Forces. 
until the Battle of Alamein in November, 1942 and the sulphonamides were not to be displaced by penicillin until 1943 . From then on war surgery advanced to meet challenges with a standard never before achieved.

In the years that have elapsed since the Second World War there has been a sorry succession of conflicts in various parts of the world (Table 1) and many have been

\begin{tabular}{|c|c|c|c|}
\hline \multicolumn{4}{|c|}{$\begin{array}{c}\text { Table 1 } \\
\text { Conflicts since } 1945\end{array}$} \\
\hline $\begin{array}{l}\text { 1945-54 Indo-China } \\
\text { 1946-49 Palestine } \\
\text { 1947-49 Greece } \\
1948 \text { Palestine } \\
\text { 1948-60 Malaya } \\
\text { 1950-53. Korea }\end{array}$ & $\begin{array}{l}\text { 1951-54 Egypt } \\
1953-59 \text { Kenya } \\
1955-60 \text { Cyprus } \\
1956 \quad \text { Israel-Egypt } \\
1958-62 \text { Algeria } \\
1960-61 \text { Congo }\end{array}$ & $\begin{array}{l}1962 \\
1963-66 \\
1963-64 \\
1963- \\
1964-67 \\
1967\end{array}$ & $\begin{array}{l}\text { China-India } \\
\text { Borneo } \\
\text { Cyprus } \\
\text { Vietnam } \\
\text { Yemen \& Aden } \\
\text { Israel-Egypt }\end{array}$ \\
\hline
\end{tabular}

insurrectionary:in which terrorism has featured. Each has taken its toll of human life and it is doubtful if statistics will ever reveal the extent of human suffering involved and the loss of life incurred. The fate of the casualties in these campaigns has depended not only on the medical organisation and surgical skill, but on the climate and standard of living of the belligerents. In certain respects the French Indo-China War (1945-54) and the Congo War (1960-61) may have been among the worst campaigns to endure.

In this address I would like first to consider some of the ballistic work done since the war and then to dwell on a few of the many aspects of missile injuries in the post-war years.

\section{Wound ballistics}

During the Second World War Black, Burns and Zuckerman (1941) had been able to demonstrate the effects of high velocity missiles on gelatine blocks and rabbits' legs using spark shadow-photography. Since then high speed cinematography and high intensity X-ray exposures at millionths of a second have been used to provide more detailed information of these effects and my survey has drawn liberally from the papers of French and Callender (1962), Uffelman (1963), Hopkinson and Marshall (1967) and others.

It had long been known that for a missile travelling above the speed of sound the ideal ballistic shape was that of a bullet, that is, with a pointed end and designed to present a minimal area combined with the maximal possible mass. Otherwise the more irregular the shape of the missile the more apt it would be to whirl and tumble through the air.

The range and consistency of trajectory of bullets and shells are dependent on their stability in flight, which is achieved by a spin imparted by the rifling on the gun barrel. The longer the bullet relative to its calibre the higher is the rate of spin required to prevent tumbling. Stability, however, can be disturbed by other factors such as deformation of the bullet when it is fired, which can cause a sideways kick on emergence from the barrel and a periodic rotational deviation from the flight axis, called yaw. Yaw can also be induced by imperfections in the rifling and in the bullet, by movements both within the barrel and by the barrel itself, and by the sudden blast of escaping gases from the muzzle. All these irregular oscillations are damped down by the gyroscopic 
effect of spin but may recur when the bullet penetrates media denser than air, such as water or body tissues.

A wound results from the absorption of kinetic energy imparted by a missile when it strikes and penetrates the body. The energy can be computed from the formula $\mathrm{KE}=\frac{1}{2} \mathrm{MV}^{2}$, where $\mathrm{KE}=\mathrm{Kinetic}$ energy, $\mathrm{M}=$ Mass, and $\mathrm{V}=$ Velocity, from which it will be seen that the smaller the mass of the missile the more important will be the part played by its velocity in wound production.

The measurement of energy release is facilitated in experimental work by using a spherical missile which eliminates spin, tumble and yaw. Thus the energy loss of a sphere in traversing body tissues is proportional to its mass and the square of its striking velocity, but it is also affected by its presenting area, the density and drag of the tissues and the distance penetrated. It is on these factors that the wounding effect of the sphere depends. They are-laceration and crushing of tissue: compression by radial shock waves: temporary cavitation. These effects are aggravated by missiles of other shapes whether they be bullet-shaped or irregular.

Laceration and crushing of tissue are most evident with low velocity missiles where the damage is confined to the missile track.

Whilst cutting out a track a striking missile compresses the medium ahead of it and initiates shock waves of short duration which travel ahead and outwards at the velocity of sound (approximately $4800 \mathrm{ft} / \mathrm{sec}$ ) in the medium, and with high velocity missiles the pressures induced can be well over $1000 \mathrm{lbs} / \mathrm{sq}$ inch.

Temporary cavitation has been described by Thoresby (1967). As the penetrating missile releases its energy it is absorbed by the tissue particles, imparting to them, due to their inertia, an acceleration which flings them forwards and outwards, enlarging the missile track by more than 30 times the diameter of the bullet and 18 times the volume of the track (Silliphant and Bayer, 1956). The result is a temporary pulsating cavity in which pressure is subatmospheric. The duration of this cavity is no more than a few milliseconds during which it collapses, leaving a macerated track called the permanent cavity. The temporary cavity can be observed by high-speed, high-intensity X-ray exposures. Its shape depends on the shape and presentation of the missile.

The passage of a steel sphere fired through a block of gelatin gel to simulate soft tissue illustrates the sequence in this phenomenon. On penetrating the block the temporary cavity has a conical shape, and from its base on the block entrance-face there is a tail splash of gelatin fragments ejected backwards. Travelling on, there is a steady. diminution in the diameter of the cavity and the conical shape becomes more fusiform as velocity is lost. The sphere then emerges, pushing gelatin ahead of it as a head cone which broadens out before subsiding. The temporary cavity collapses : rapidly with successively smaller pulsations, ending with an indrawing of the entrance and exit faces and violent displacement of the whole block. With a yawing bullet there would be several large temporary fusiform cavities connected by small ones (Fig. 2).

\section{Wounds of the human body}

Similar changes take place in missile wounds of human or animal tissue: The skin has a relative resistance to penetration by a missile and although an entrance wound may give an indication of the missile's presentation at the moment of impact, neither 


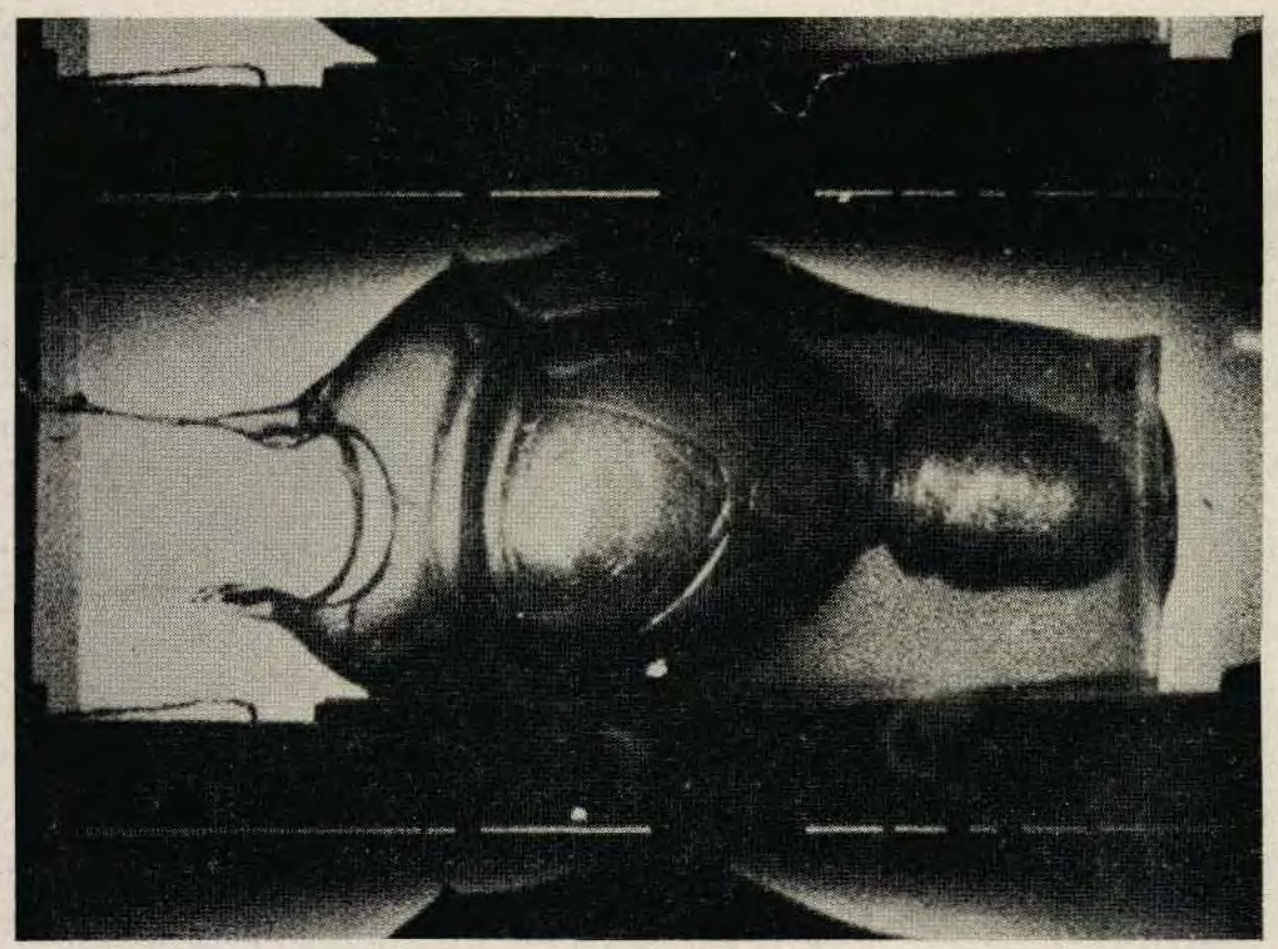

Fig. 2

Temporary cavity in a gelatine block caused by the passage of a yawing bullet.

entrance nor exit wounds, nor the residual permanent track will give any idea of the extensive distortion and destruction which have taken place.

The stretching and rupture of tiny blood vessels caused by the rapidly expanding wall of the temporary cavity results in bruising, haemorrhage, vascular stasis and oedema around the missile track. This may be quite extensive following penetration by missiles at velocities over $2000 \mathrm{ft} / \mathrm{sec}$.

The production of shock waves and of temporary cavitation explains the explosive effects so often reported. They can account for tissue pulping and for the stretching of nerves to such a degree that conductivity can be impeded without naked eye damage. Sometimes there is splitting along fascial planes of muscle at some distance from the track. Gas-and fluid-filled viscera can be blown asunder by hydraulic pressure, an effect which is also observed in liver and muscle. Large vessels, being more resilient, may be uninjured though forces may be transmitted through the non-compressible blood stream to rupture a vein at some distance from the missile track. Bone can be fractured without evidence of a direct hit. In the skull the passage of a missile of sufficiently high velocity can cause the formation of a temporary cavity in the brain, and burst the skull.

Irregular metal fragments from bursting grenades, bombs, mines and shells are ballistically unstable and show less tendency to produce the explosive effects of high velocity bullets, and their weight and the resistance of the tissues of different density impede penetration. They tend to develop bizarre tracks and to lodge in the tissues 
causing large ragged wounds in which bits of clothing are embedded. Metal fragments can have high velocities in the immediate vicinity of a burst and can cause fatal damage if a vital organ or large vessel is penetrated.

Hopkinson and Watts (1963) have studied these effects and have shown the extent of tissue damage by dye perfusion and by histology in sheep muscle wounded by a 0.22 inch bullet. Postmortem indian ink perfusion showed a zone of ischaemic and necrotic muscle surrounding the bullet track and around this there was a zone of less severe, and reversible damage (Hopkinson, 1964). Under experimental conditions and in the absence of major blood vessel damage and sepsis, the bullet wounds healed spontaneously.

\section{Wound Contamination}

The presence, just described, of haemorrhage and blood (especially intra-muscular), ischaemia and tissue necrosis round the missile track provides an ideal pabulum for bacterial multiplication. While it has now been experimentally confirmed that bullets are not sterilised by the heat of friction in flight (Thoresby and Darlow, 1967) wound contamination is not only the result of foreign material and organisms being carried in by the penetrating missile. Experiments reported in this decade have proved that contaminating matter is also sucked in by the partial vacuum within the instantaneous pulsating cavity produced by the missile (Ziperman, 1961, Thoresby and Darlow, 1967).

The bruising and necrosis in wounded tissue and the ease with which contamination occurs makes it reasonable to assume that all, especially high velocity, missile wounds are contaminated with organisms and therefore potentially infected. The source of bacterial contamination has been shown to be the skin and clothing especially in the vicinity of the perineum (MacLennan, 1942) and the soil from animal excreta. Wounds of the thighs and buttocks are particularly prone to infection, especially clostridial infection, for they involve large muscle masses and are near the source of clostridia excreted from the bowel.

\section{Weapons and exploding devices}

The succession of armed conflicts in many parts of the world since the Second World War points to the existence of an enormous quantity of arms and explosives. These range from the antiquated to the most modern and sophisticated, from crude sawn-off shotguns and home-made bombs to automatic machine guns and rocket missiles. The incidence of accidental wounds resulting from these is significant. Watts (1960) recorded 213 out of 704 G.S.W.

Modern weapons have become more destructive, more automatic and highly accurate at increasing ranges. Revolvers and pistols are relatively inaccurate except at very close quarters. The 0.38 inch revolver bullet has a muzzle velocity of $600 \mathrm{ft} / \mathrm{sec}$ and its range is not more than 100 yards. On the other hand, the $9 \mathrm{~mm}$ bullets of the light automatic Sterling sub-machine gun or carbine (Fig. 3) can be fired at 180 rounds per minute with a muzzle velocity of $1000 \mathrm{ft} / \mathrm{sec}$ with an effective range of up to 200 yards."

The postwar rifle has become the most accurate of weapons. The N.A.T.O. service rifle is the Belgian (FN) $7.62 \mathrm{~mm}$ self-loading rifle (SLR) (Fig. 4). It is light, easy to operate and reliable. Its $7.62 \mathrm{~mm}$ bullet has a muzzle velocity of $2600 \mathrm{ft} / \mathrm{sec}$ and an effective wounding range up to 800 yards. Its automatic version is the General Purpose 


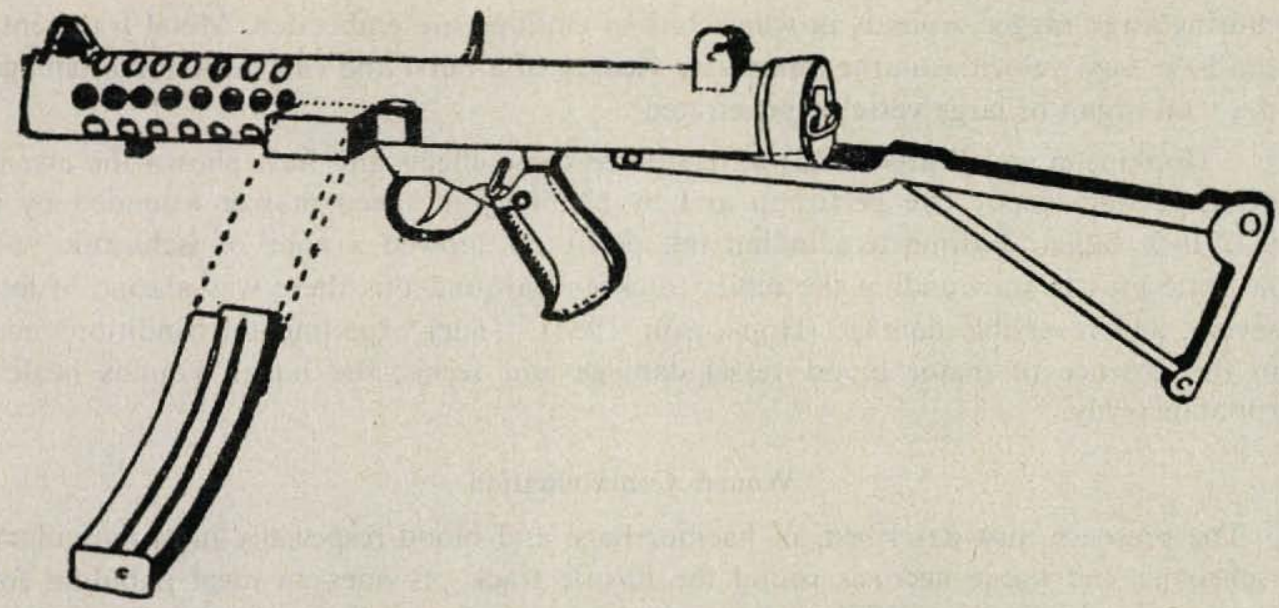

Fig. 3.

The $9 \mathrm{~mm}$ Sterling sub-machine gun.

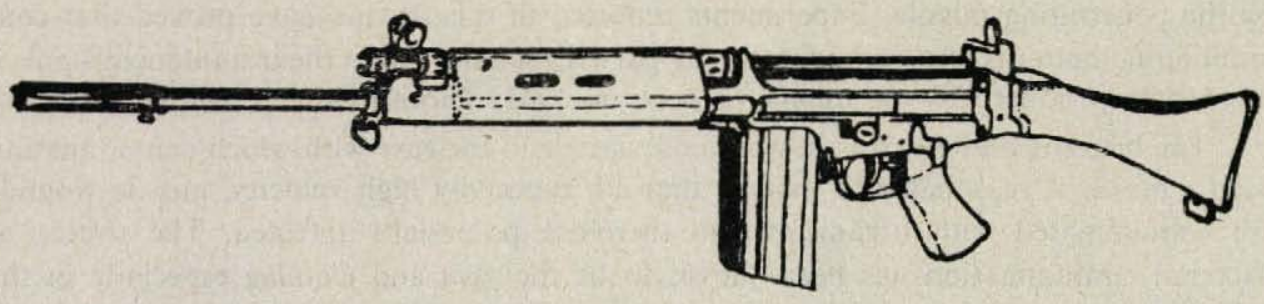

Fig. 4.

The $7.62 \mathrm{~mm}$ F.N. self-loading rifle.

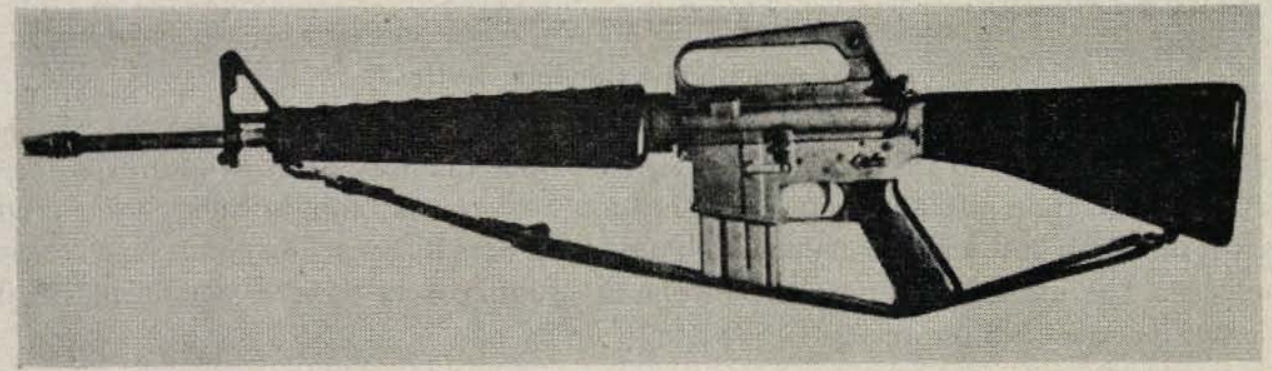

Fig. 5.

The Colt Armalite rifle.

sub-machine gun which fires 1000 rounds per minute with a muzzle velocity of $2600 \mathrm{ft} / \mathrm{sec}$ and a wounding range of 2000 yards.

A recently introduced rifle is the American Colt Armalite rifle (Fig. 5), very much lighter than the FN rifle, having a plastic stock. It fires a 0.223 inch bullet which is less than half the weight of the $7.62 \mathrm{~mm}$ bullet and has a higher muzzle velocity $(3250 \mathrm{ft} / \mathrm{sec})$ and a severe wounding effect, but is less accurate than the FN rifle at longer ranges. 


\section{Fragmenting missiles}

The bursting of a device containing high explosive creates blast and throws out metal fragments of irregular shape and size, the smallest of which can attain velocities up to $4000 \mathrm{ft} / \mathrm{sec}$ and can produce ragged wounds with tissue damage comparable to that of high velocity bullets. A favourite weapon of terrorists is the grenade, which has a cast-iron, grooved body to ensure maximal fragmentation, and contains high explosive T.N.T. Bombs similarly are metal containers with a detonator, fuse and high explosive. No less injurious are home-made bombs; the simplest of these which I have seen are bottles, or even bits of iron piping filled with blasting powder, with or without nails. Of a similar nature are land-mines and anti-personnel mines. In Vietnam a favourite Viet-Cong routine was to submerge anti-personnel mines just below the surface of water in paddy fields. Some of these contained rice-grain lead pellets and all produced highly contaminated (the paddies were manured with human and animal excreta) mutilating multiple wounds of the lower extremities and buttocks.

The list is incomplete as I have not mentioned mortar bombs, incendiary, armourpiercing and concrete-blasting bombs, shells and rockets. Only one other deserves mention and that is the evil napalm bomb filled with jellied petrol which produces not only fragment wounds, and blasting effects, but also severe burns on those in the vicinity of its burst.

\section{Analysis of Wounding Agents}

In all campaigns since the Second World War wounds have been caused by conventional weapons. Table II shows that while in the First World War fragmentation

Table II

Wounding Agents

(Approximate percentages)

\begin{tabular}{lccccc}
\hline Missile & $\begin{array}{c}\text { World War 1 } \\
\text { British }\end{array}$ & $\begin{array}{c}\text { World War II } \\
\text { British }\end{array}$ & $\begin{array}{c}\text { Korea } \\
\text { United States } \\
1950-51\end{array}$ & $\begin{array}{c}\text { Borneo } \\
\text { British } \\
1963-65\end{array}$ & $\begin{array}{c}\text { Vietnam* } \\
\text { United States }\end{array}$ \\
\hline $\begin{array}{l}\text { Fragment } \\
\text { Bullet }\end{array}$ & 61 & 85 & 92 & $?$ & 44 \\
Other & 39 & 10 & 70 & 52 & 4 \\
\hline
\end{tabular}

* 5 Months (October 1965-February 1966)

wounds were twice as common as bullet wounds they were eight times more common in the Second World War. In the Korean War 92 per cent of wounds in the American forces were due to missile fragments. On the other hand, in the much smaller Borneo confrontation, there was a very high incidence of bullet wounds due to skirmishes involving small groups of combatants. Among American casualties in Vietnam, for a very limited period of the five winter months of 1965-66, bullet wounds showed a slight proponderance over fragmentation wounds. Of more disabling than statistical significance were foot wounds sustained by stepping on to pointed " punji " bamboo stakes driven into paddy fields just below the surface of the water. 
Regional Distribution of Wounds

Table III illustrates the vulnerability of various regions of the body. The most

\begin{tabular}{|c|c|c|c|c|c|c|c|}
\hline \multicolumn{8}{|c|}{$\begin{array}{l}\text { Table III } \\
\text { Wounds-Regional distribution } \\
\text { (Approximate percentages) }\end{array}$} \\
\hline Region & $\begin{array}{l}\text { World } \\
\text { Britain }\end{array}$ & $\begin{array}{l}\text { War I } \\
\text { United } \\
\text { States }\end{array}$ & $\begin{array}{l}\text { World } \\
\text { Britain }\end{array}$ & $\begin{array}{l}\text { War II } \\
\text { United } \\
\text { States }\end{array}$ & $\begin{array}{c}\text { Korea } \\
\text { United States } \\
1950-51\end{array}$ & $\begin{array}{c}\text { Borneo } \\
\text { British } \\
1963-65\end{array}$ & $\begin{array}{c}\text { Vietnam } \\
\text { United States }\end{array}$ \\
\hline $\begin{array}{l}\text { Head \& Neck } \\
\text { Chest } \\
\text { Abdomen } \\
\text { Extremities } \\
\text { Other }\end{array}$ & $\begin{array}{r}17 \\
4 \\
2 \\
70 \\
7\end{array}$ & $\begin{array}{r}11 \\
4 \\
3 \\
82 \\
-\end{array}$ & $\begin{array}{r}4 \\
8 \\
4 \\
75 \\
9\end{array}$ & $\begin{array}{r}19 \\
11 \\
6 \\
64 \\
\end{array}$ & $\begin{array}{r}16 \\
8 \\
6 \\
69 \\
1\end{array}$ & $\begin{array}{l}12 \\
12 \\
19 \\
57 \\
\end{array}$ & $\begin{array}{r}11 \\
8 \\
6 \\
62 \\
13\end{array}$ \\
\hline \multicolumn{8}{|c|}{ * 5 Months (October 1965-February 1966) } \\
\hline
\end{tabular}

striking feature is the consistently high proportion of wounds of the extremities, in all the campaigns shown. A feature not easy to show is the increasing number of multiple wounds from automatic weapons and fragmentation missiles.

\section{Severity of Wounds}

Figures showing severity of wounding are difficult to obtain but nearly one third of wounds received by British forces overseas in 1965 were severe, a high proportion of these were multiple and as many as half of the severe wounds involved the trunk.

\section{Casualty Collection and Evacuation}

Experience of postwar campaigns has continued to emphasise the value of first aid life-saving measures to ensure that the wounded man survived to benefit by resuscitation and surgery. The main immediate causes of death from missile injuries have still been haemorrhage, asphyxia and shock, and chest wounds. Experience has proved that there is a continuing need to train not only medical orderlies but all servicemen in simple measures to control haemorrhage, prevent asphyxia in unconscious casualties and to splint injured limbs. Such measures have been invaluable in preventing fatalities. On the other hand, Wright (1956) noted instances in the Korean War where simple first aid had been omitted, and at the same time he drew attention to the dangers of oversedation in casualties where first aid measures would have been more appropriate.

In addition to first aid, speedy evacuation of the shocked and wounded man to surgery is essential and the use of the helicopter in postwar campaigns has been a major factor in the saving of lives of casualties who would otherwise have arrived shocked, moribund or dead after a tedious and rough ambulance journey. In spite of their limitations, helicopters were a boon in the long Indo-China and Malayan campaigns, and they were essential in the roadless jungles of Borneo and the Congo, as they were in the scattered trouble spots of Algeria and in the arid and hilly Radfan of the Aden hinterland. They played a vital role in the difficult terrain of Korea, bringing wounded from battalion aid posts direct to the Mobile Army Surgical Hospital. Here the American 
Army for the first time began to have Medical Service Helicopter Units exclusively for forward aeromedical casualty evacuation. This service has been developed on an unprecedented scale in Vietnam where the proud boast has been that no soldier is more than 35 minutes away from full hospital surgical facilities. It should be realised, however, that such an intensive use of helicopters has been possible only in the absence of enemy air superiority.

In internal security operations such as in Cyprus (1956-60) when casualties arrived in manageable numbers at a time, the proximity of hospitals was such that, with little necessity for further evacuation, primary life saving and subsequent surgery was possible at the same hospital. This was also true of Malaya (1948-60) and recently in Aden. In contrast, however, the distances involved in the Borneo campaign (1963-66), and the distances and larger numbers of casualties in the Indo-China War (1945-54) and Korea (1950-53) made long journeys necessary after primary surgery. In Korea this involved in many cases a road journey, then a rail journey, and either a flight or sea voyage to base hospitals in Japan. The profound travel weariness observed in such postoperative patients and their need of a good rest before subsequent surgery has been recorded by both Latta (1951) and Wright (1956) in their reports on casualties from Korea.

\section{Shock and Resuscitation}

Wound shock has continued to be a fascinating problem. Much more is known about it since Grant and Reeve (1951) showed that when the blood volume fell below 75 per cent of normal, shock would appear and that it could be lethal if corrective measures were inadequate or delayed. Resuscitation has become a prominent routine feature of war surgery and, in addition to the replacement of fluid loss by blood and similar fluids, there is a growing awareness of the need to give sodium bicarbonate to correct the metabolic acidosis accompanying shock to preserve adequate myocardial function (Peretz et al, 1964). Surgery has been withheld until the systolic blood pressure was brought up to above $100 \mathrm{~mm}$ mercury. On the other hand failure to respond early to dextran and blood transfusion, suggesting continuing haemorrhage, has been the signal for prompt exploration.

In my own experience intra-arterial blood transfusion has not been used, nor has it been used to any significant extent by others (Wright, 1956, Watts, 1960, Aulong and Gaillard, 1956).

In resuscitation plasma has yielded to dextran as a volume expander. For the oliguria of impending renal failure intravenous mannitol has proved to be a valuable diuretic.

Prompt first aid and rapid helicopter evacuation have brought an increasing number of live casualties to the surgeon, and it is not surprising that the quantity of blood used in transfusion has greatly increased. In the Second World War the average quantity of blood used per casualty amounted to 0.5 units. In Korea it rose to 0.9 units per casualty, in Borneo 1.5 units, and so far in the Vietnam war the figure has reached nearly 3 units per casualty for both first and second stage surgery (Moffat, 1967).

Despite the striking improvement in survival rates of wounded men in campaigns since the Second World War, Huston (1958) was already concerned about the problem of providing enough blood to meet the increasing demand. Crosby (1964), in reviewing the overall consumption rate of 0.9 units of blood per casualty in the Korean War, 
somewhat dispassionately contended that this figure was due to the too ready availability of blood, which was often used both unnecessarily and instead of blood substitutes, and to the flow of casualties being steady enough for the surgeons to do full justice to each case, and that complications had arisen from giving too much blood. On the other hand, he considered that the particular circumstances leading to such a high consumption figure had little relevance to planning blood supplies for nuclear warfare, where mass casualties might overwhelm medical resources and in which rigid selection would be necessary to focus treatment on good risk cases, whose needs of blood would be negligible, at the expense of poor risk cases.

\section{The Surgical Treatment of Missile Wounds}

The policy of wound excision, debridement and delayed primary suture for wounds was developed during the First World War. It was relearnt during the Second World War and then distilled into the Field Pocket Book of Surgery (1962) and has continued to apply in all campaigns since. Though there has been a wide divergence of opinion as to what constituted adequate wound excision especially in a fresh wound and to the inexperienced eye, the penalty of failure to carry out a thorough exploration, evacuation of blood clot, relief of fascial and intramuscular tension, and excision of damaged tissue in missile wounds has been high. Moffat (1967) reported that "a minor wound may become a major problem, and such minor wounds may exist with serious wounds elsewhere in the same patient." To the hard-pressed forward surgeon casualties with multiple mine wounds have consumed much valuable operating time in order to achieve thorough debridement and this has had to be weighed up against the dangers of delay in operating on other patients. This dilemma could be resolved only by careful sorting of cases into priority for surgery and it could be learnt only by experience.

While expeditious thoroughness was always called for in the primary operative procedure there was no justification for the time-wasting search for hidden foreign bodies attempted by inexperienced surgeons, nor for internal fixation of missile wound fractures.

\section{Primary Suture}

Experience in most postwar campaigns has shown that with certain exceptions primary wound suture with and without drainage has courted disaster especially where the casualty has had to be evacuated postoperatively within the next 48 hours. The sutured wound has inevitably broken down following oedematous tension which has encouraged sepsis. This has led in turn to a prolonged hospital stay, loss of limb and even fatal gas gangrene in spite of antibiotic cover. Clyne (1954) did report successful primary wound suture in a few selected cases but these must be attributed to very thorough debridement and a minimum of two weeks' after-care by the same surgeon under good hospital conditions.

The only circumstances under which primary wound suture has been permissible after thorough wound debridement, irrigation and careful haemostasis, have been in wounds of the face, and in the hands where it was essential to provide some cover without tension to exposed tendons and nerves. The serous cavities of joints, abdomen and chest (the latter with drainage) must be closed after excision of damaged tissue but the nverlying skin should be left open for delayed primary suture. 
There has been no change in the policy of avoiding tension in any form after primary wound toilet whether it be primary suture, potentially constrictive encircling bandages or unsplit plasters, especially in patients who were likely to be evacuated within 48 hours of operation. In the case of wounds of the thigh and leg the claims of the Tobruk splint have remained undisputed.

Leaving the wounds open, covered with a simple dressing, has facilitated drainage and subsidence of oedema. Wheatley (1967) has stressed, from experience at British Military Hospital, Singapore during the Borneo confrontation, the importance of postponing delayed primary suture beyond the routine 3-5 days if oedema persisted, especially in wounds of the forearm and leg. Where doubt existed split skin grafts were better than suture.

\section{Intrathoracic Wounds}

Although chest wounds have tended to be among the most fatal, prompt collection of these casualties and efficient first aid combined with skilled resuscitation, anaesthesia and surgery have been responsible for saving many lives. Wright (1956) observed that in the Korean War chest wounds were twice as common as in the Second World War but that only an insignificant number ( 2.9 per cent) were penetrating wounds. This was probably due to the wearing of body armour which was the practice in the American forces. Latta (1951), referring to his experience of caring for postoperative chest cases on a hospital ship plying between Korea and Japan, observed that their unstable state involved meticulous supervision. Drainage tubes tended to block on account of their small calibre and tension pneumothorax was a common emergency.

\section{Intra-abdominal Wounds}

In the French Indo-China campaign severe abdominal wounds had a very high early mortality and those casualties who survived 24 hours had a significantly smaller death rate. Experience in all campaigns has shown that wounds in the region of the second part of the duodenum, and at the mesenteric and mesocolic edge of the bowel cannot afford to be overlooked.

Application of the lessons of the Second World War in subsequent campaigns has undoubtedly produced improved results in the treatment of abdominal wounds. Rapid evacuation to hospital, prompt transfusion, and postoperative retention in hospital have been main factors in the good results. Statistics from various sources are very difficult to correlate because of the infinite variety of factors involved though Marangos et al (1962) made a bold attempt. They stated that in seven surgical centres in the IndoChina war the postoperative mortality was about 41 per cent. In Algeria (1955-58) with civilian casualties it was 22 per cent. In Malaya it was 16.7 per cent (Clyne (1954) and in the Korean War where the American forces were supported by an excellent medical organisation the postoperative mortality was reduced to 10 per cent. Marangos' team's mortality figures for civilian casualties in Cyprus (1955-58) were 20 per cent (10/50) and, during roughly the same period in Cyrpus, Watts (1960) had a postoperative mortality of 11 per cent $(8 / 73)$. (Table IV).

\section{Major Blood Vessel Damage}

Perhaps the most important advance in surgical technique during the Korean War was the application in special surgical units of the principle of wound excision (debridement) to the surgical repair of major blood vessel damage (Seeley, 1960). 


\begin{tabular}{|c|c|c|c|}
\hline \multicolumn{4}{|c|}{$\begin{array}{c}\text { Table IV } \\
\text { Post-operative mortality rates } \\
\text { Intra-abdominal wounds }\end{array}$} \\
\hline Theatre & Percentage & Theatre & Percentage \\
\hline $\begin{array}{l}\text { French Indo-China } \\
\text { Malaya (Clyne) } \\
\text { Korea }\end{array}$ & $\begin{array}{l}41 \\
16.7 \\
10\end{array}$ & $\begin{array}{l}\text { Algeria } \\
\text { Cyprus (Marangos et al) } \\
\text { Cyprus (Watts) }\end{array}$ & $\begin{array}{l}22 \\
20 \\
11\end{array}$ \\
\hline
\end{tabular}

In addition to the excision of devitalised wound tissue and of the damaged blood vessel segment at least one $\mathrm{cm}$ of the apparently undamaged ends of the vessel was also excised and invariably showed histological evidence of intimal damage. This finding probably explained the vascular repair failure rate in previous campaigns, and which in the Second World War had resulted in an amputation rate of about 55 per cent of vascular repairs. This rate fell to 15 per cent in Korea. In Vietnam the relative stability, and excellent facilities of forward hospitals have enabled such techniques to be further developed and the failure or amputation rate in blood vessel surgery has fallen to 12 per cent, though there was still a 40 per cent complication rate due to sepsis and thrombosis for which inadequate wound excision may have been a contributory factor.

\section{Infection and Antibiotics}

The routine early administration of antibiotics has continued to play an important role in the prevention of serious infection in missile wounds but has failed to do so where initial wound toilet has been inadequate or where tension has been encouraged by premature wound closure and by constrictive bandages and plasters.

Wright (1956) observed that of the wounds treated at the British and Commonwealth Hospital in Japan from the Korean War, 9 per cent were infected, most of them superficially, but that 2 per cent were massive stinking wounds attributable to inadequate surgery. He saw no gas gangrene but Latta (1951) reported three cases in 1850 casualties transferred from Korea to Japan by sea. These had had penicillin and inadequate surgery.

In a survey of British casualties occurring overseas in 1965, just less than half the severe wounds and a quarter of the less severe wounds showed some degree of infection postoperatively in spite of antibiotics. Fortunately the sepsis was mostly superficial and was usually proportional to the severity of tissue damage and pre-operative delay.

Moffat (1967) reported an infection incidence of nearly 3 per cent in 60 Australian postoperative casualties received in 1965-66 from Vietnam. He considered that hospital cross-infection with $P$ s. pyocyanea was probably responsible for half of the serious sepsis which occurred in 11 severe wounds.

In his series of 60 patients there were two cases of gas gangrene in men with multiple low velocity mine wounds of the lower limbs: both required above-knee amputation.

\section{The Reckoning}

The mortality among wounded reaching hospitals and surviving 24 hours has continued to show a downward trend in conflicts since the Second World War when it was 4.5 per cent. 
In the Malayan troubles it was 3.3 per cent, in Korea (1951-53) 2.2 per cent, in Cyprus (1955-60) 3 per cent, and in Vietnam it has fallen to less than 1.5 per cent. While these campaigns differed in many respects, especially in the numbers of men engaged, the figures must take into account air and artillery superiority. The saving of life must be attributed to improved first aid measures, to medical organisation and equipment, to the use of helicopters and to the increased use of blood, all of which have enabled the surgeon to give of his best.

\section{Conclusion}

My survey has shown that missile wounds since the Second World War have coninued to be of a conventional nature. We know more about the wounding effects of missiles, and weapons have increased in their destructive power. Although the wounded man has benefited from speedier evacuation, antibiotics and more blood transfusion, the keystone of treatment is still early and adequate wound exploration and excision of damaged tissue while wound closure should await the subsidence of oedema.

The fortunes of war threw Alex Simpson-Smith and myself together for a brief span. I shall always treasure the memory of his inspiring example. He was a dedicated and skilled surgeon and a brave man. For the opportunity of paying this tribute to him I am grateful.

\section{REFERENCES}

Black, A. N., Burns, B. D. and Zuckerman, S. (1941). Brit. med. J., 2, 872.

Clyne, J. (1954). Brit. med. J., 2, 10.

Crosby, W. H. (1964). Ann. N.Y. Acad. Sci., 115, 399.

French, R. V. and Callender, G. R. (1935). Milit. Surg. 77, 177.

French, R. V. and Callender, G. R., in "Wound Ballistics (1962) Office of the Surgeon General, Department of the Army, Washington D.C., Ed. J. B. Coates.

Grant, R. T. and ReEve, E. B. (1951). Spec. Rep. Ser. Med. Res. Coun., 277.

Hopkinson, D. A. W. (1964). J. Path. Bact., 87, 63.

Hopkinson, D. A. W. and Marshall, T. K. (1967). Brit. J. Surg., 54, 344.

Hopkinson, D. A. W. and WatTs, J. C. (1963). Proc. roy. Soc. Med. 56, 461.

Huston, J. (1958). J. roy. Army med. Cps., 104, 133.

LATTA, R. M. (1951). Lancet, i, 228.

Maclennan, J. D. (1943). Lancet, ii, 94.

Maclennan, J. D. (1962). Bact. Rev. 26, 2.

Marangos, G. N., Economides, C., Koliandris, L., Keus, V., Christopoulos, C. S. and Dafnies, A. (1962). J. roy. Army med. Cps. 108, 62.

Moffat, W. C. (1967). J. roy. Army med. Cps., 113, 25

O'BallancE, E. (1966). "Malaya: the Communist Insurgent War, 1948-60", London, Faber and Faber Ltd.

Peretz, D. I., McGregor, M. and Dosseter, J. B. (1964). Canad. med. Ass. J., 90, 673.

SeEley, S. F. (1960). J. Amer. med. Ass., 173, 518.

Silliphant, W. and BAyer, L. (1956). Milit. med., 117, 38.

Thorseby, F. P. (1966). J. roy, Army med. Cps.., 112, 89.

Thoresby, F. P. and Darlow, H. M. (1967). Brit. J. Surg. 54, 359.

Thoresby, F. P. and Matheson, J. M. (1967). J. roy. Army med. Cps., 113, 31.

ThoresBy, F. P. and WATTS, J. C. (1967). Brit. J. Surg. 54, 25.

Uffelman, F. L. (1963). Proc. roy. Soc. A., 272, 331.

WatTs, J. C. (1960). Ann. roy, Coll. Surg. Engl., 27, 125.

Wheatley, P. R. (1967). J. roy. Army med. Cps., 113, 18.

Wright, D. (1956). Lancet, ii, 505.

Ziperman, H. H. (1961). J. Traima, 1, 361. 